\title{
Determination of heavy metals in exposed corned beef and chicken luncheon that sold in Sulaymaniah markets
}

\author{
Hozan Jalil Hamasalim and Hemin Nuradden Mohammed \\ Animal Production, Faculty of Agricultural Science, University of Sulaimani, Iraq. \\ Accepted 17 June, 2013
}

\begin{abstract}
In this study, the levels of heavy metals (Cr, Cd, Co, Pb, Cu, Ni, Fe, $\mathrm{Zn}, \mathrm{Mg}$ and $\mathrm{Mn}$ ) were determined in canned beef and four different chicken luncheon from Sulaymaniah markets using atomic absorption spectroscopy (AAS). Significant difference was observed in the chromium (Cr) content among the corned beef brands, while there was no-significant difference in $\mathrm{Cr}$ content in the all chicken luncheon trademarks. The results of cobalt (Co) for $A, B, C$ and $D$ were $(0.03,0.04,0.04$ and $0.08 \mu \mathrm{g} / \mathrm{gm}$, respectively). Co concentration for Gadeer, $F, G$ and $H$ were $0.00,0.03,0.04$ and $0.04 \mu \mathrm{g} / \mathrm{gm}$, respectively. Lead $(\mathrm{Pb})$ and copper $(\mathrm{Cu})$ were significantly different among all trademarks. Manganese $(\mathrm{Mn})$ and nickel (Ni) were not found in any of the corned beef and chicken luncheon trademarks. The iron (Fe) content for the corned beef trademarks was $1.43,5.41,3$ and $4.4 \mu \mathrm{g} / \mathrm{gm}$ ) for $\mathrm{A}, \mathrm{B}, \mathrm{C}$ and $\mathrm{D}$ respectively. The results also reveal that there was a significant difference in Fe content between chicken luncheon trademarks. $B$ and $C$ contained a high concentration of $\mathrm{Zn}$ while $A$ and $D$ had low concentration of $\mathrm{Zn}$. Furthermore, the $\mathrm{F}$ trademark was significantly higher in $\mathrm{Zn}$ concentration than $\mathrm{G}$ trademark, which showed significantly lower concentration of $\mathrm{Zn}$.
\end{abstract}

Key words: Canned beef, chicken luncheon and heavy metals determination.

\section{INTRODUCTION}

Applying food safety standards on a product is very important because it relates closely to human's health. Good food products have a high nutritional quality, as well as being free from physical, chemical and biological contaminations. The food industry development encourages food manufacturer's to produce more practical and durable products, but still must have high nutrition. For example, beef processing to produce meatballs, corned beef, beef burgers and sausages have the purpose to form more practical and durable products, as well as having high nutritional value. The presence of some metal pollutants in everywhere; especially, cadmium $(\mathrm{Cd})$, lead $(\mathrm{Pb})$, chromium ( $\mathrm{Cr}$ ), arsenic (As), nickel (Ni) and mercury $(\mathrm{Hg})$; spread out into animal rations and food chains, thus it may increase the possibility of toxic effects in humans and animals (Farmer and Farmer, 2000; Javed et al., 2009).

Meat is a very rich and convenient source of nutrients, also to large extent microelements. The chemical composition of meat depends on both kind and degree of the feeding animal. The need for mineral compounds depends on the age, physiological state and feed intake as well as on living conditions (Baykov et al., 1996). Heavy metals from manmade pollution sources are continuously released into aquatic and terrestrial ecosystems and therefore the concern about the effect of anthropogenic pollution on the ecosystems is growing. Contamination with heavy metals is a serious threat 
Table 1. Concentrations of heavy metals $(\mu \mathrm{g} / \mathrm{gm})$ in four trademarks of corned beef.

\begin{tabular}{|c|c|c|c|c|c|c|c|c|c|c|}
\hline Trademark & $\mathrm{Cr}$ & $\mathrm{Cd}$ & Co & $\mathrm{Pb}$ & $\mathrm{Cu}$ & $\mathrm{Ni}$ & $\mathrm{Fe}$ & $\mathrm{Zn}$ & $\mathrm{Mg}$ & Mn \\
\hline A & $\begin{array}{l}0.20 \pm \\
0.100^{b}\end{array}$ & $\begin{array}{l}0.07 \pm t \\
0.004^{\mathrm{b}}\end{array}$ & $\begin{array}{l}0.03 \pm \\
0.005^{b}\end{array}$ & $\begin{array}{l}0.53 \pm \\
0.020^{d}\end{array}$ & $\begin{array}{l}0.11 \pm \\
0.005^{d}\end{array}$ & $\begin{array}{c}0.00 \pm \\
0.00\end{array}$ & $\begin{array}{l}1.43 \pm \\
0.005^{d}\end{array}$ & $\begin{array}{l}2.43 \pm \\
0.015^{d}\end{array}$ & $\begin{array}{l}2.51 \pm \\
0.005^{\mathrm{d}}\end{array}$ & $\begin{array}{c}0.00 \pm \\
0.00\end{array}$ \\
\hline B & $\begin{array}{l}0.10 \pm \\
0.000^{b}\end{array}$ & $\begin{array}{l}0.06 \pm \\
0.001^{b}\end{array}$ & $\begin{array}{l}0.04 \pm \\
0.020^{b}\end{array}$ & $\begin{array}{l}0.61 \pm \\
0.020^{c}\end{array}$ & $\begin{array}{l}0.27 \pm \\
0.020^{b}\end{array}$ & $\begin{array}{c}0.00 \pm \\
0.00\end{array}$ & $\begin{array}{l}5.41 \pm \\
0.015^{\mathrm{a}}\end{array}$ & $\begin{array}{l}3.81 \pm \\
0.015^{\mathrm{a}}\end{array}$ & $\begin{array}{l}4.32 \pm \\
0.005^{\mathrm{a}}\end{array}$ & $\begin{array}{c}0.00 \pm \\
0.00\end{array}$ \\
\hline C & $\begin{array}{l}0.19 \pm \\
0.095^{b}\end{array}$ & $\begin{array}{l}0.27 \pm \\
0.060^{\mathrm{a}}\end{array}$ & $\begin{array}{l}0.04 \pm \\
0.010^{b}\end{array}$ & $\begin{array}{l}1.53 \pm \\
0.035^{b}\end{array}$ & $\begin{array}{l}0.17 \pm \\
0.010^{c}\end{array}$ & $\begin{array}{c}0.00 \pm \\
0.00\end{array}$ & $\begin{array}{l}3.00 \pm \\
0.100^{c}\end{array}$ & $\begin{array}{l}3.16 \pm \\
0.005^{b}\end{array}$ & $\begin{array}{l}3.80 \pm \\
0.025^{b}\end{array}$ & $\begin{array}{c}0.00 \pm \\
0.00\end{array}$ \\
\hline D & $\begin{array}{l}0.40 \pm \\
0.100^{\mathrm{a}}\end{array}$ & $\begin{array}{l}0.20 \pm \\
0.050^{\mathrm{a}}\end{array}$ & $\begin{array}{l}0.08 \pm \\
0.030^{\mathrm{a}}\end{array}$ & $\begin{array}{l}2.07 \pm \\
0.060^{a}\end{array}$ & $\begin{array}{l}0.32 \pm \\
0.025^{a}\end{array}$ & $\begin{array}{c}0.00 \pm \\
0.00\end{array}$ & $4.40 \pm 0.00^{b}$ & $\begin{array}{l}2.48 \pm \\
0.025^{\mathrm{c}}\end{array}$ & $\begin{array}{l}3.61 \pm \\
0.015^{c}\end{array}$ & $\begin{array}{c}0.00 \pm \\
0.00\end{array}$ \\
\hline
\end{tabular}

Means having the same letter in the same sections are not significantly different at $P \leq 0.05$ according to Duncan tests.

because of their toxicity, bioaccumulation and biomagnifications in the food chain (Demirezen and Uruc, 2006). The risk of heavy metal contamination in meat is of great concern for both food safety and human health because of the toxic nature of these metals at relatively minute concentrations (Santhi et al., 2008). Instances of heavy metal contamination in meat products during processing have been reported (Santhi et al., 2008 and Brito et al., 2005).

Heavy metal pollutants can contaminate the products during processing (through the raw material, spices, water and packaging) by inhalation of air and penetration through the skin's surface (Raikwar et al. 2008 and Santhi et al., 2008). In other cases, contaminated animal feed and rearing of livestock in proximity to polluted environment were reportedly responsible for heavy metal contamination in meat (Miranda et al., 2005 and Sabir et al., 2003).

The objective of this investigation was to find out whether the level of metallic elements in corned beef and chicken luncheon obtained from Sulaymaniah Market in Iraq for human consumption have exceeded the maximum permissible level specified by international standards.

\section{MATERIALS AND METHODS}

\section{Sample collection}

Samples included canned beef for four different trademarks (A, B, $C$ and D) of Brazilian origin and Chicken luncheon for four different trademarks, $E$ and $F$ of Jordan origin while $G$ and $H$ of France origin, were collected from the Sulaymaniah Market in Sulaymaniah governorate, Iraq. The samples were collected beginning in May, 2012 and transported to the laboratory for analysis.

\section{Ash content}

Ash content was determined according to the method of AOAC (2000) by taking a specimen of known weight of flesh and placing in a muffle furnace at $550^{\circ} \mathrm{C}$ for $16 \mathrm{~h}$.

\section{Sample preparation}

The ash was dissolved in $5 \mathrm{ml}$ of $\mathrm{HCl}$ acid and $5 \mathrm{ml}$ of distillated water and put on a hot plate for 5 min after which it was topped up to $25 \mathrm{ml}$ with double distillated water.

\section{Elemental analysis of samples}

$\mathrm{Cr}, \mathrm{Cd}, \mathrm{Co}, \mathrm{Pb}, \mathrm{Cu}, \mathrm{Ni}, \mathrm{Fe}, \mathrm{Zn}, \mathrm{Mg}$ and $\mathrm{Mn}$ in corned beef and chicken luncheon samples were determined directly on each sample of the final solutions using atomic absorption spectroscopy (AAS).

\section{Statistical analysis}

All data were subjected to one-way analysis of variance (ANOVA) using $\mathrm{XL}$ Stat program for windows. Differences between the means were tested by Duncan tests. The level of significance was chosen at $\mathrm{P}<0.05$ and the results are presented as mean (Steel et al., 1996).

\section{RESULTS AND DISCUSSION}

Tables 1 and 2 show the concentration of heavy metals in some trademarks of corned beef and chicken luncheon. The ranges of metal concentrations found in the canned corn beef samples were as follows: Cr: 0.10 to $0.40 \mu \mathrm{g} / \mathrm{g}$ $(\bar{x}=0.22 \mu \mathrm{g} / \mathrm{g})$; Cd: 0.06 to $0.27 \mu \mathrm{g} / \mathrm{g}(\bar{x}=0.60 \mu \mathrm{g} / \mathrm{g})$; Co: 0.03 to $0.08 \mu \mathrm{g} / \mathrm{g}(\bar{x}=0.48 \mu \mathrm{g} / \mathrm{g})$; $\mathrm{Pb}: 0.53$ to 2.07 $\mu \mathrm{g} / \mathrm{g}(\bar{x}=1.3 \mu \mathrm{g} / \mathrm{g}) ; \mathrm{Cu} 0.11$ to $0.32 \mu \mathrm{g} / \mathrm{g}(\bar{x}=0.21$ $\mu \mathrm{g} / \mathrm{g})$; Fe: 1.43 to $5.41 \mu \mathrm{g} / \mathrm{g}(\bar{x}=3.42 \mu \mathrm{g} / \mathrm{g}) ; \mathrm{Zn}: 2.43$ to $3.81 \mu \mathrm{g} / \mathrm{g}(\bar{x}=3.12 \mu \mathrm{g} / \mathrm{g})$ and $\mathrm{Mg}: 2.51$ to $4.32 \mu \mathrm{g} / \mathrm{g}(\bar{x}$ $=3.41 \mu \mathrm{g} / \mathrm{g}$ ). The ranges of metal concentrations found in the canned Chicken luncheon samples were as follows: Cr: $0.10 \mu \mathrm{g} / \mathrm{g}$; Cd: 0.06 to $0.10 \mu \mathrm{g} / \mathrm{g}(\bar{x}=0.08 \mu \mathrm{g} / \mathrm{g})$; Co: 0.00 to $0.04 \mu \mathrm{g} / \mathrm{g}(\bar{x}=0.02 \mu \mathrm{g} / \mathrm{g}) ; \mathrm{Pb}: 0.52$ to $1.19 \mu \mathrm{g} / \mathrm{g}$ ( $\bar{x}=0.85 \mu \mathrm{g} / \mathrm{g})$; Cu: 0.15 to $0.30 \mu \mathrm{g} / \mathrm{g}(\bar{x}=0.22 \mu \mathrm{g} / \mathrm{g})$; Fe: 2.55 to $4.22 \mu \mathrm{g} / \mathrm{g}(\bar{x}=3.38 \mu \mathrm{g} / \mathrm{g}) ; \mathrm{Zn}: 1.59$ to 3.08 $\mu \mathrm{g} / \mathrm{g}(\bar{x}=2.33 \mu \mathrm{g} / \mathrm{g})$ and $\mathrm{Mg}: 2.16$ to $4.16 \mu \mathrm{g} / \mathrm{g}(\bar{x}=3.16$ $\mu \mathrm{g} / \mathrm{g})$.

The significant difference $(p<0.05)$ in the chromium $(\mathrm{Cr})$ 
Table 2. Concentrations of heavy metals $(\mu \mathrm{g} / \mathrm{gm})$ in four trademarks of Chicken Luncheon.

\begin{tabular}{|c|c|c|c|c|c|c|c|c|c|c|}
\hline Trademark & $\mathrm{Cr}$ & Cd & Co & $\mathrm{Pb}$ & $\mathrm{Cu}$ & $\mathrm{Ni}$ & $\mathrm{Fe}$ & $\mathrm{Zn}$ & $\mathrm{Mg}$ & Mn \\
\hline $\mathrm{E}$ & $0.10 \pm 0.00^{\mathrm{a}}$ & $0.10 \pm 0.00^{\mathrm{a}}$ & $0.00 \pm 0.000^{b}$ & $1.19 \pm 0.010^{a}$ & $0.24 \pm 0.005^{b}$ & $0.00 \pm 0.00$ & $3.14 \pm 0.010^{b}$ & $2.00 \pm 0.005^{c}$ & $2.16 \pm 0.015^{d}$ & $0.00 \pm 0.00$ \\
\hline $\mathrm{F}$ & $0.10 \pm 0.00^{a}$ & $0.06 \pm 0.003^{c}$ & $0.03 \pm 0.005^{a}$ & $1.02 \pm 0.005^{\mathrm{a}}$ & $0.30 \pm 0.000^{a}$ & $0.00 \pm 0.00$ & $4.22 \pm 0.020^{a}$ & $3.08 \pm 0.010^{a}$ & $4.16 \pm 0.010^{a}$ & $0.00 \pm 0.00$ \\
\hline$G$ & $0.10 \pm 0.00^{a}$ & $0.08 \pm 0.001^{b}$ & $0.04 \pm 0.010^{a}$ & $1.00 \pm 0.300^{a}$ & $0.15 \pm 0.010^{c}$ & $0.00 \pm 0.00$ & $2.55 \pm 0.005^{d}$ & $1.59 \pm 0.000^{d}$ & $3.06 \pm 0.050^{c}$ & $0.00 \pm 0.00$ \\
\hline
\end{tabular}

Means having the same letter in the same sections are not significantly different at $P \leq 0.05$ according to Duncan test.

was recorded among the corned beef trademarks. The $\mathrm{D}$ trademark contained a high concentration of $\mathrm{Cr}$, while the $\mathrm{B}$ trademark contained low concentration of $\mathrm{Cr}$. There were no-significant differences in $\mathrm{Cr}$ content of all chicken luncheon trademarks.

Significant differences in cadmium (Cd) were shown among the corned beef trademarks, C trademark appeared to have higher content of $\mathrm{Cd}$ $(0.27 \mu \mathrm{g} / \mathrm{gm})$ but the $\mathrm{B}$ trademark had a lower content of $\mathrm{Cd}(0.06 \mu \mathrm{g} / \mathrm{gm})$. The $\mathrm{E}$ trademark had the highest value $(0.1 \mu \mathrm{g} / \mathrm{gm})$ while the $\mathrm{F}$ trademark showed the lowest value $(0.06 \mu \mathrm{g} / \mathrm{gm})$. The distribution of cadmium into the food is often through water, air and soil. In humans and animals, cadmium contamination is usually caused by the food chain (Zhuang et al., 2009). Cadmium is absorbed around five percent and the remaining passes directly into the feces. Gastrointestinal absorption of cadmium in the digestive tract is influenced by several factors; one of them is low-calcium diet that causes higher absorption and deposition of cadmium into the intestinal mucosa, liver, and kidney (Kazantzis, 2004). The accumulation of cadmium in the liver and kidneys seems to be mainly dependent on the storage of cadmium in association with cadmiumbinding protein, metallothionein (Ellah and Yahia, 2009). Cadmium may accumulate in the human body and may induce kidney dysfunction, skeletal damage and reproductive deficiencies.

The recommended consumer dietary exposure of $\mathrm{Cd}$ are $0.12 \mu \mathrm{g} / \mathrm{kg}$ body weight/day for adult, $0.315 \mu \mathrm{g} / \mathrm{kg}$ body weight/day for toddlers (1.5 to 4.8 ) and $0.22 \mu \mathrm{g} / \mathrm{kg}$ body weight/day for young people (FSIS, 2004). The testimonial consume dietary exposures of $\mathrm{Cr}$ are $1.7 \mu \mathrm{g} / \mathrm{kg}$ body weight/day for toddlers and $1.15 \mu \mathrm{g} / \mathrm{kg}$ body weight/day for young people (FSIS, 2004).

The results of cobalt (Co) as shown in Table 1 for $A, B, C$ and D were $(0.03,0.04,0.04$ and 0.08 $\mu \mathrm{g} / \mathrm{gm}$, respectively). Cobalt concentration for $\mathrm{E}$, $\mathrm{F}, \mathrm{G}$ and $\mathrm{H}$ were $0.00,0.03,0.04$ and $0.04 \mathrm{\mu g} / \mathrm{gm}$, respecttively. Significant differences were found between all trademarks $(P<0.05)$. The results in Table 1 show significant differences in the lead $(\mathrm{Pb})$ concentration among all trademarks. $\mathrm{D}$ trademark recorded higher $\mathrm{Pb}$ concentration $(2.07$ $\mu \mathrm{g} / \mathrm{gm})$ while A trademark contained $(0.53 \mu \mathrm{g} / \mathrm{gm})$ low levels of $\mathrm{Pb}$. Lead concentrations for $\mathrm{E}, \mathrm{F}, \mathrm{G}$ and $\mathrm{H}$ were $1.19,1.02,1$ and $0.52 \mu \mathrm{g} / \mathrm{gm}$ respectively. All trademarks varied significantly $(\mathrm{P}<0.05)$. The concentrations of heavy metals $\mathrm{Pb}$ and $\mathrm{Cd}$ in the liver, kidneys and most of meat products have been described by researchers in other countries (Kirkpatrick and Coffin, 2006 Gonzaacutelez-Weller et al., 2006; Santhi, et al., 2008; Blanco-Penedo et al., 2009). The commendation consumer dietary exposure of $\mathrm{Pb}$ is $18 \mu \mathrm{g} \mathrm{kg}^{-1}$ for adult, $46 \mu \mathrm{g} \mathrm{kg}^{-1}$ for toddlers and
$30 \mathrm{\mu g} \mathrm{kg}^{-1}$ for young people (FSIS, 2004). Lead would become toxic if it is consumed in the amount which exceeds the threshold and can cause acute and chronic poisoning symptoms (Jarup, 2003). Lead is known to induce reduced cognitive development and intellectual performance in children and increase blood pressure and cardiovascular disease in adults (Comission of the European, 2002). The source of $\mathrm{Pb}$ contamination of food livestock come from the air, water, food materials, cooking utensils and food packaging. The use of spices during processing of meatballs, corned beef, burger's beef and sausages is one of the sources of lead pollution. Plants absorb lead from the soil and the air around resulting in further accumulation (Landis and Ming-Ho, 2004). According to the recommendation of the Central Agency for Standardization and Quality Control of Iraq (1988), the $\mathrm{Pb}$ threshold is $1 \mathrm{mg} / \mathrm{kg}$ in luncheon meat.

There was significant difference in Copper (Cu) concentration which appeared in all trademarks; higher $\mathrm{Cu}$ concentration value was detected in $\mathrm{D}$ trademark but lower $\mathrm{Cu}$ concentration was detected in A. Table 2 shows the mean value for $\mathrm{Cu}$ concentration of chicken luncheon trademarks. Generally, $\mathrm{Cu}$ concentration were higher in $\mathrm{F}$ while $E$ showed amid concentration, and $G$ and $H$ trademarks showed rather low concentrations of 
Cu. Mariam et al. (2004) reported higher concentration of copper in mutton, beef and poultry meat from some region such as Lahore region. Copper can also cause public health hazards in high concentrations (Brito et al., 2005). According to the recommendation of the Central Agency for Standardization and Quality Control of Iraq (1988) Cu should not exceed $15 \mathrm{mg} / \mathrm{kg}$ in luncheon meat. The best consumer dietary exposure of $\mathrm{Cu}$ are 18 , 46 and $30 \mu \mathrm{g} / \mathrm{kg}$ body weight/day for adult, toddlers and young people, respectively (FSIS, 2004).

The result does not show any trace of manganese $(\mathrm{Mn})$ and nickel $(\mathrm{Ni})$ in any of corned beef and chicken luncheon trademarks. Nickel (Ni) can cause respiratory problems and is a carcinogen (Agency for Toxic Substance and Disease Registry, 2004). The upper tolerable $\mathrm{Ni}$ intake for children (one to three years old) and adults (19 to 70 years old) is 7 and $40 \mathrm{mg} /$ day, respectively. The highest mean level of $\mathrm{Ni}$ was found in turkey meat samples collected from Warri zone (20.78 $\left.\mathrm{mg} \cdot \mathrm{kg}^{-1}\right)$. The levels of $\mathrm{Ni}$ found in these samples did not exceed the upper tolerable intake levels of this element.

Daily intake of small amounts of $\mathrm{Mn}$ is needed for growth and good health in humans, otherwise deficiency of Mn can cause nervous system problems (Demirezen and Uruç, 2006). Consumer dietary exposure of $\mathrm{Mn}$ are $67 \mu \mathrm{g} / \mathrm{kg}$ body weight/day for adult, $132 \mu \mathrm{g} / \mathrm{kg}$ body weight/day for toddlers (1.5 to 4.8 ) and $101 \mu \mathrm{g} / \mathrm{kg}$ body weight/day for young people (4 to 18) (FSIS, 2004).

The iron (Fe) concentration for the corned beef trademarks were $(1.43,5.41,3$ and $4.4 \mu \mathrm{g} / \mathrm{gm})$ for $\mathrm{A}, \mathrm{B}, \mathrm{C}$ and $D$, respectively, significant differences were shown among all trademarks. The Fe concentrations of chicken luncheon trademarks are illustrated in Table 2. There was a significant $\mathrm{Fe}$ concentration $(\mathrm{P}<0.05)$ between chicken luncheon trademarks.

$\mathrm{B}$ and $\mathrm{C}$ contained high concentration of $\mathrm{Zn}$ (3.81and $3.16 \mu \mathrm{g} / \mathrm{gm}$, respectively), while $A$ and $D$ had low concentration of $\mathrm{Zn}(2.43$ and $2.48 \mu \mathrm{g} / \mathrm{gm}$, respectively). Furthermore, the $F$ trademark showed significantly higher $\mathrm{Zn}$ concentration than $\mathrm{G}$ trademark. Trace $\mathrm{Zn}$ can cause problems; however, too much $\mathrm{Zn}$ is harmful to human health (ATSDR, 2004). The recommended daily intakes of zinc are $15 \mathrm{mg}$ for adult males and $12 \mathrm{mg}$ for adult females. The highest average of zinc concentration (1.7 $\mu \mathrm{g} \mathrm{g}^{-1}$ ) was observed in "HAMOON" brand and the lowest average zinc concentration was observed in "DARYA" $\left(0.41 \mathrm{\mu g} \mathrm{g}^{-1}\right)$. The United States Environmental Protection Agency and the European Commission (US-EPA and EC)(2001) have not considered any standards or limits for the zinc concentrations (Ashraf et al., 2006). According to the recommendation of the Central Agency for Standardization and Quality Control of Iraq (1988), Zn should not exceed $50 \mathrm{mg} / \mathrm{kg}$ in luncheon meat.

\section{Conclusion}

From the results of this study, the concentrations of all the heavy metals in the canned beef and chicken luncheon were found to be statistically significant. The levels of each heavy metals $(\mathrm{Cr}, \mathrm{Cd}, \mathrm{Co}, \mathrm{Pb}, \mathrm{Cu}, \mathrm{Fe}, \mathrm{Zn}$ and $\mathrm{Mg}$ ) in the canned beef differed significantly; the heavy metal in the chicken luncheon $(\mathrm{Cd}, \mathrm{Co}, \mathrm{Pb}, \mathrm{Cu}, \mathrm{Fe}$, $\mathrm{Zn}$ and $\mathrm{Mg}$ ) also differed significantly among the different trademarks; while, the Mn and Ni were not found in all of each canned beef and Chicken luncheon.

\section{REFERENCES}

Agency for Toxic Substances and Disease Registry (ATSDR) (2004). Agency for Toxic Substances and Disease Registry, Division of Toxicology, Clifton Road, NE, Atlanta, GA. Retrieved from: http://www.atsdr.cdc.gov/toxprofiles/.

Ashraf W (2006). Levels of selected heavy metals in tuna fish. Arabian J. Sci. Eng. 31(1A):89.

Association of Official Analytical Chemists (AOAC) (2000). Meat and Meat products. In: Official Methods of Analysis. Association of Official Analytical Chemists Inc. Gaithersburg, U.S.A.

Baykov BD, Stoyanov MP, Gugova ML (1996). Cadmium and lead bioaccumulation in male chickens for high food concentration. Toxicol. Environ. Chem. 54:155-159.

Blanco-Penedo JL, Benedito RF, Shore M, Miranda M, García V, López-Alonso M (2009). Influence of farm type (organic, conventional and intensive) on toxic metal accumulation in calves in NW Spain. Agron. Res. 7:578-584.

Brito G, Díaz C, Galindo L, Hardisson A, Santiago D, Montelongo FG (2005). Levels of metals in canned meat products: Intermetallic correlations. Bull. Environ. Contam. Toxicol. 44(2):309-316.

Central Agency for Standardization and Quality Control (1988). Luncheon meat.UDC, 664-531. No. 1431.

Commission of the European communities (2001). Commission regulation (EC) No. 221/ 2002 of 6 February 2002 amending regulation (EC) No. 466/2002 setting maximum levels for certain contaminants in foodstuffs. Off. J. Eur. Commun. Brussels, 6 February 2002.

Demirezen D, Urue K (2006). Comparative study of trace elements in certain fish, meat and product. Meat Sci. 74(2):255-260.

Farmer AA, Farmer AM (2000). Concentrations of cadmium, lead and zinc in livestock feed and organs around a metal production center in eastern azakhstan. Sci. Total Environ. 257(1): 53-60.

Food Safety and Inspection Service (FSIS) (2004). 2000 Total Diet Study of 12 elements - aluminium, arsenic, cadmium, chromium, copper, lead, manganese, mercury, nickel, selenium, tin and zinc. Food Survey Information Sheets.48/04.www: http://www.food.gov.uk/science/surveillance/.

Gonzaacutelez-Weller D, Karlsson L, Caballero A, Hernaacutendez F, Gutieacuterrez A, Gonzaacutelez-Iglesias T, Marino M, Hardisson A (2006). Lead and cadmium in meat and meat products consumed by the population in Tenerife Island, Spain. J. Food Add. Contam. 23:757-763

Jarup $L$ (2003). Hazards of heavy metal contamination. Br. Med. Bull. 68:167-182.

Javed I, Jan I, Muhammad F, Zia-ur-Rahman, M Zargham, B Aslam and JI Sultan (2009). Heavy metal residues in the milk of cattle and goats during winter season. Bull. Environ. Contam. Toxicol. 82: 616-620.

Kazantzis G (2004). Cadmium, osteoporosis and calcium metabolism. J. Biometals 17(5):493-498.

Kirkpatrick DC, Coffin DE (2006). Cadmium, lead and mercury content of various cured meats. J. of Sci. of Food and Agric. 24(12):15951598.

Landis WG, Ming-Ho Yu (2004). Introduction to Environmental Toxicology; Impacts of Chemicals Upon Ecological System. Lewis Publishers, CRC Press, LLC. pp. 221-223.

Mariam I, Iqbal S, Nagra AS (2004).Distribution of some trace macro minerals in beef, mutton and poultry. Int. J. Agric. Biol. 5:816.

Miranda M, Lopez-Alonso M, Castillo C, Hernandez J, Prieto F, Benedito JL (2003). Some toxic elements in liver, kidney and meat 
from calves slaughtered in Asturias (Northern Spain). Eur. Food Res. Technol. 216, 284-289.

Raikwar M, Kumar P, Singh M, Singh A (2008). Toxic effect of Heavy metals in livestock health. Vet. World 1(1): 28-30.

Sabir SM, SW Khan, I Hayat (2003). Effect of environmental pollution on quality of meat in district Bagh, Azad Kashmir. Pak. J. Nutr. 2(2): 98-101.

Santhi D, Balakrishnan V, Kalaikannan A, Radhakrishnan KT (2008). Presence of heavy metals in pork products in Chennai (India). Am. J. Food Technol. 3(3):192-199.
Steel RGD, Torrie JH, Dickey DA (1996). Principles and procedures of statistics. A biometrical approach. 3rd ed. McGraw Hill Book Company Inc, New York, USA. pp. 334-381.

Zhuang P, Zou H, Shu W (2009). Biotransfer of heavy metal in meat. J. Environ. Sci. 21(6):849-855. 